\title{
Jurisdiction in International Human Rights Law: Application of the European Convention to Soldiers Deployed Overseas
}

\author{
Richard C Watkins*
}

\begin{abstract}
Jurisdiction has a specific meaning in public international law. As an instrument of regulating inter-state relationships, the laws of jurisdiction ensure mutual respect of sovereignty by largely limiting the lawful reach of states' power to their own territories - territory being an important concept in notions of statehood and sovereignty. Jurisdiction also appears in human rights law. However, it has been given an altogether different interpretation by human rights treaty bodies. The European Convention on Human Rights obliges states parties to secure and ensure the Convention rights to everyone within their jurisdiction. But what does jurisdiction mean in this sense? In its jurisprudence, the European Court of Human Rights has adopted a number of different conceptions of jurisdiction, ranging from the position in Bankovic that closely resembled the public international law limitation to territory; to the Al-Skeini judgment that a state's jurisdiction for the purposes of the Convention extends to anyone under the authority and control of its agents. In this article, I shall examine the European Court's jurisprudence, exploring the different approaches adopted in a number of key cases. The article also analyses the UK Supreme Court's approach to the meaning of 'authority and control' as it relates to British soldiers deployed overseas. Finally, the article discusses the implications of the human rights notion of jurisdiction without territory.
\end{abstract}

KEYWORDS: European Convention on Human Rights, jurisdiction, authority and control, extraterritorial application, overseas soldiers

\section{Introduction}

The relationship between jurisdiction, sovereignty and territory is complicated and has been a topic of debate for many years. Public international law ('PIL') governs the nature and conduct and states and their relationships with one another. In this body of law, jurisdiction defines the limits of a state's authority to make and enforce rules of conduct upon individuals. ${ }^{1}$ States' powers to prescribe and enforce their will is strongly tied to territory, not least because territory

\footnotetext{
* Doctoral Candidate, University of Nottingham.

${ }^{1}$ Vaughan Lowe and Christopher Staker, 'Jurisdiction' in Malcolm D Evans (ed), International Law, 3rd edn (Oxford, Oxford University Press, 2010) 313-339, 313.
} 
is a prerequisite for statehood (and all the powers that confers) in customary international law. ${ }^{2}$ Limiting states' powers to their own territories also respects the sovereign equality of states, itself an important principle of PIL, ${ }^{3}$ by preventing states from exercising their own powers on the territories of other states. Though the scope of states' powers is defined primarily in relation to their territories, in certain circumstances states' rights and duties may extend beyond those territories. Numerous international human rights instruments require states parties to guarantee the rights detailed therein to all persons within their jurisdiction. ${ }^{4}$ The meaning of jurisdiction in these instruments has been the subject of academic and curial debate.

This article examines the nature and meaning of jurisdiction in international human rights law ('IHRL'), especially in the context of the European Convention on Human Rights ('the ECHR') and how it has been interpreted to subject state agents ${ }^{5}$ to human rights obligations anywhere in the world. International human rights tribunals have adopted an interpretation of jurisdiction with only a tenuous link to territory. IHRL is found in multilateral treaties, which are part of the body of treaties forming one of the main sources of PIL. ${ }^{6}$ This article analyses the implications for PIL of a break in the traditional doctrinal link between territory and jurisdiction. The article presents the hypothesis that jurisdiction in IHRL is a very different concept to that in PIL, and that this is because the nature of states' obligations arising out of IHRL instruments prevents the link between territory and jurisdiction from being replicated in human rights doctrine. Furthermore, this article suggests that there is no need for a territorial notion of jurisdiction in IHRL at all.

Many states deploy their armed forces abroad, on peacekeeping missions or active combat operations. There are a number of grounds in PIL that permit states to act outside their own borders. The traditional concept of jurisdiction, closely linked as it is to notions of territory

\footnotetext{
${ }^{2}$ Article 1 (b), Convention on Rights and Duties of States adopted by the Seventh International Conference of American States, 26 December 1933, in force 26 December 1934, 165 LNTS 3802.

${ }^{3}$ Though the principle of the equality of states can be traced back to the Peace of Westphalia (1648) and even further back to the Peace of Augsburg (1555), it was formalised in Article 2 (1), Charter of the United Nations, 26 June 1945, in force 24 October 1945, 1 UNTS XVI.

${ }^{4}$ Article 1, Convention for the Protection of Human Rights and Fundamental Freedoms (European Convention on Human Rights, as amended) (ECHR), 4 November 1950, in force 3 September 1953, 213 UNTS 222; Article 2 (1), International Covenant on Civil and Political Rights (ICCPR), 16 December 1966, in force 23 March 1976, 999 UNTS 171; Article 1, American Convention on Human Rights (ACHR), 22 November 1969, in force 18 July 1978, 1144 UNTS 123.

${ }^{5}$ All references to 'state agents' in this article should be taken to include those bodies and all other individuals authorised to act on a state's behalf, whose actions would be attributable to the state under the provisions in Articles 4-5, International Law Commission, 'Draft Articles on Responsibility of States for Internationally Wrongful Acts' UN General Assembly Resolution (UNGA Res) 56/83 (28 January 2002), UN Doc A/Res/56/83.

${ }^{6}$ Article 38 (1) (d), Statute of the International Court of Justice, 26 June 1945, in force 24 October 1945, USTS 993.
} 
and sovereignty, determines the legality of this deployment and of the soldiers' actions abroad. Do the same principles govern the application of human rights treaties to states' extraterritorial activities? The now-defunct European Commission on Human Rights ('the Commission') said there is no reason that the acts of a state's authorities abroad could not entail liability under the ECHR. ${ }^{7}$ Academics have since argued that 'there is no a priori reason to limit a state's obligation to respect human rights to its national territory'. ${ }^{8}$ In its decided cases, the European Court of Human Rights ('the European Court') has considered the extent of states' extraterritorial obligations under the ECHR and has evinced a number of general principles on the meaning of jurisdiction for the purposes of Article 1 of the ECHR. The treaty bodies of the American Convention on Human Rights ('the ACHR') and the International Covenant on Civil and Political Rights ('the ICCPR') have taken their cues from the European Court in interpreting the relevant treaty provisions. In their judgments, the tribunals have adopted a definition of jurisdiction that has only the most tenuous link to a state's territory. This article analyses the treaty bodies' approaches to jurisdiction and states' obligations to uphold individuals' human rights when acting abroad as well as at home.

The treaty bodies have all examined extraterritorial application of human rights obligations through the lens of state agents as the perpetrators of alleged human rights violations. But the extraterritorial application of human rights obligations also raises the issue of whether those state agents acting abroad are themselves entitled to human rights protection. In Smith (No 1) $)^{9}$ and Smith (No 2), ${ }^{10}$ the Supreme Court of the United Kingdom ('UKSC') dealt with the question of whether British soldiers deployed on combat operations to Iraq are "within the jurisdiction' of the United Kingdom for the purposes of the ECHR and therefore whether the United Kingdom was bound by its ECHR obligations in respect of those service personnel during the course of their deployment. These two cases are the only UKSC cases dealing with the issue of extraterritorial application of the ECHR to soldiers. The UKSC's different approach in Smith (No 2) demonstrates some of the conflicting ideas about jurisdiction in IHRL. This article considers the approach of the UKSC and the basis for guaranteeing soldiers' human rights when deployed abroad.

\footnotetext{
${ }^{7}$ Hess v United Kingdom, Application no 6231/77, European Commission on Human Rights, Decision (28 May 1975), 2 Decisions \& Reports (1975) 72, 73.

${ }^{8}$ Theodor Meron, 'The Extraterritoriality of Human Rights Treaties' (1995) 89 American Journal of International Law 78-82, 80.

${ }^{9} R$ (Smith) $v$ Secretary of State for Defence and Another (2010) UKSC 29, (2011) 1 AC 1 (hereafter 'Smith (No 1)').

${ }^{10}$ Smith v Ministry of Defence (2013) UKSC 41, (2014) AC 52 (hereafter 'Smith (No 2)').
} 
The next section of this article sets out the normative framework of the scope of obligations under the relevant international human rights treaties and the treaty bodies' interpretations of the concept of jurisdiction. The UKSC's application of the European Court's general principles of jurisdiction are the focus of Section 3. Finally, in Section 4, I set out the implications of these judgments for the relation between territory and jurisdiction in PIL. The European Court and the other treaty bodies that have followed a similar tack, appear to have broken or at least substantially weakened the link between jurisdiction and territory. But arguably what those tribunals have done is developed a whole new concept of jurisdiction to meet the needs of the human rights instruments, rather than adapting the existing doctrine that governs inter-state relationships.

\section{Legal Framework}

The ECHR, ICCPR and ACHR all impart an obligation on states to guarantee the rights contained therein to individuals within or subject to their jurisdiction, with some important variations in wording. The scope of the rights and freedoms in the ECHR and states parties' attendant obligations are expressly limited in Article 1. The European Court has confirmed that the ECHR is only binding upon states that consent to be so bound and that contracting states are not required to impose ECHR standards on non-contracting states. ${ }^{11}$ But it does not necessarily follow that states' human rights obligations end at their own borders. Article 1 provides thus:

Article 1 - Obligation to respect human rights

The High Contracting Parties shall secure to everyone within their jurisdiction the rights and freedoms defined in Section I of this Convention. ${ }^{12}$

In common parlance, the territory within which a state exercises its authority may be referred to as a jurisdiction. The use of the 'within' preposition in the English-language version of Article 1 could suggest, at first glance, that the obligation to respect ECHR rights extends to everyone within the state's territory. But the French-language version of Article 1 (which is of equal authoritative value) requires states to secure the Convention rights to everyone 'relevant

\footnotetext{
${ }^{11}$ Soering v United Kingdom, Application no 14038/88, European Court of Human Rights, Judgment (7 July 1989), para 11

${ }^{12}$ Article 1, ECHR (emphasis added).
} 
de leur juridiction'. ${ }^{13}$ In French, 'juridiction' does not have the same territorial connotations, unless qualified as 'juridiction territoriale'. 'Juridiction' relates to the power or right to exercise legal authority, it does not denote the territory to which that power or right is limited. 'Relevant' means under or subject to. One can be under or subject to legal authority, but not to territory. As such, the initial interpretation of Article 1 jurisdiction as coterminous with a state's territory is clearly wrong.

The ACHR similarly limits the scope of states parties' obligations:

Article 1

The States Parties to this Convention undertake to respect the rights and freedoms recognised herein and to ensure to all persons subject to their jurisdiction the free and full exercise of those rights and freedoms ... ${ }^{14}$

Just as under the ECHR, the scope of rights and freedoms in the ACHR is limited according to states parties' jurisdiction, but there is no explicit mention of territory. An individual cannot be subject to a territory, so obviously the application of the ACHR is not limited to states parties' national territories either.

The ICCPR contains a similar clause, although it does make reference to territory in its delimitation of states' obligations:

Article 2

(1) Each State Party to the present Covenant undertakes to respect and to ensure to all individuals within its territory and subject to its jurisdiction the rights recognised in the present Covenant ... ${ }^{15}$

The ICCPR explicitly provides that states parties must secure the Covenant rights to everyone within their national territories, but it is unclear whether 'and subject to its jurisdiction' merely describes individuals within a state's territory or creates a separate category of individuals who are outside the state's territory but who still have enforceable rights against the state under the Covenant. The Human Rights Committee confirmed in its General Comment No 31 that Article 2(1) of the ICCPR binds states to ensure the Covenant rights to those individuals 'within the power or effective control' of the state's forces acting outside its territory. ${ }^{16}$ As such, the IHRL instruments limit the scope of the obligations arising under their terms to states' jurisdiction but

\footnotetext{
${ }^{13}$ Article 1, ECHR (Official French version, emphasis added).

${ }^{14}$ Article 1, ACHR (emphasis added).

${ }^{15}$ Article 2(1), ICCPR (emphasis added).

${ }^{16}$ UNCHR, 'General Comment No 31: The Nature of the General Legal Obligation Imposed on States Parties to the Covenant' (2004) UN Doc CCPR/C/21/Rev.1/Add.1326, para 10.
} 
not to their territories. Therefore, the meaning given to jurisdiction in this context is extremely important.

The Inter-American Commission on Human Rights has decided to adopt the meaning of jurisdiction as arrived at by the European treaty bodies. ${ }^{17}$ The UN Human Rights Committee's General Comments also support the approach taken by the European Court. The European Court's general position has been that the ECHR is usually applicable throughout a contracting state's territory. ${ }^{18}$ Jurisdiction for the purposes of the ECHR includes a state's own territory. This accords with the PIL sense of states' right to prescribe and enforce their will over their own national territories, but is meant in the sense that states owe an obligation to respect the human rights of individuals within that territory. There is a presumption that states are responsible for guaranteeing the rights of individuals within their own territories because they exercise control over those individuals. This is a rebuttable presumption. ${ }^{19}$ Where a state has lost control of portions of its territory it may be unable to fulfil some ${ }^{20}$ or indeed all of its ECHR obligations in those territories over which control has been lost. ${ }^{21}$ True enough, that control embodies the PIL understanding of jurisdiction, but it is based on more than states' rights visà-vis other states to control their own internal affairs free of external interference.

The European Court has judged that

The exercise of jurisdiction is a necessary condition for a Contracting State to be able to be held responsible for acts or omissions imputable to it which give rise to an allegation of the infringement of the rights and freedoms set forth in the Convention. ${ }^{22}$

Jurisdiction has thus been called a 'threshold criterion', ${ }^{23}$ according to which the state's liability is determined. But the European Court did not say that the necessary condition was exercise of PIL jurisdiction over territory. Instead jurisdiction should be viewed as a prima facie link between the state and an individual. When the state exercises jurisdiction over an individual it

\footnotetext{
${ }^{17}$ Coard et al v United States, Case No 10.951, Inter-American Commission on Human Rights, Report (29 September 1999); Alejandre et al v Cuba, Case No 11.589, Inter-American Commission on Human Rights, Report (29 September 1999).

${ }^{18}$ Ilasscu and others v Moldova and Russia, Application no 58787/99, European Court of Human Rights, Judgment (8 July 2004) para 113.

${ }^{19}$ Assanidzé v Georgia, Application no 71503/01, European Court of Human Rights, Judgment (8 April 2004) para 139.

${ }^{20} \mathrm{Ilașcu}$ (n 18) para 311.

${ }^{21}$ Cyprus v Turkey (No 2), Application no 8007/77, European Court of Human Rights, Judgment (2 April 1992) para 63

${ }^{22}$ Ilașcu (n 18) para 311.

${ }^{23}$ Samantha Besson, 'The Extraterritoriality of the European Convention on Human Rights: Why Human Rights Depend on Jurisdiction and What Jurisdiction Amounts To' (2012) 25 (4) Leiden Journal of International Law $857-84,857$.
} 
may be held responsible for the acts or omissions of its agents imputable to it which might infringe that individual's ECHR rights. It should be noted that jurisdiction for the purposes of Article 1 is not the same as attribution and responsibility. ${ }^{24}$ Attribution of conduct to a state is a different legal question. Whereas attribution determines that the state had control over the perpetrators of an alleged human rights violation, jurisdiction is concerned with the state's control over the victims. ${ }^{25}$

The European Court has repeatedly ruled that "the term "jurisdiction" is not limited to the national territory of the High Contracting Parties; their responsibility can be involved because of acts of their authorities producing effects outside their own territory'. ${ }^{26}$ Jurisdiction in IHRL is not a set of rules governing when states may lawfully act outside their own territory. Rather it denotes the circumstances in which states owe human rights obligations to individuals. Two main approaches to jurisdiction are discernible in the European Court's case law. In the first, an individual is within a state's jurisdiction (and therefore entitled to ECHR rights) when the agents of that state exercise power and authority over him. These agents may be soldiers, diplomats, police or other individuals acting with state authority. The power exercised may be physical or legal. This is called the personal model. In the second approach an individual is within the state's jurisdiction when he is in a territory over which that state has effective control. The territory is not necessarily a legal part of the controlling state but is under that state's control as a matter of fact. This is called the spatial model. In both of these approaches jurisdiction means the factual relationship between a state and an individual, rather than the legality of a state's actions for the purposes of PIL and inter-state relationships.

\subsection{Personal Model}

\subsubsection{Cyprus v Turkey}

Cyprus and Turkey are both states parties to the ECHR. In 1974, Turkey invaded Cyprus and came to occupy the Northern 40 per cent of the island. The Cypriot Government alleged that Turkish troops in Northern Cyprus had committed widespread violations of the ECHR. Before examining the merits of the application, the Commission had to determine whether the

\footnotetext{
${ }^{24}$ Loizidou v Turkey (Preliminary Objections), Application no 15318/89, European Court of Human Rights, Judgment (23 March 1995) para 61

${ }^{25}$ Marko Milanović, Extraterritorial Application of Human Rights Treaties: Law, Principles and Policy (Oxford, Oxford University Press, 2011) 51.

${ }^{26}$ Drozd and Janousek v France and Spain, Application no 12747/87, European Court of Human Rights, Judgment (26 June 1992) para 91.
} 
individuals affected were within Turkey's jurisdiction for the purposes of Article 1 of the ECHR (and therefore whether Turkey was a capable respondent to the application), despite those individuals being within Cyprus' sovereign territory. ${ }^{27}$

The Commission decided:

It is clear from the language, in particular, of the French text, and the object of this Article, and from the purpose of the Convention as a whole, that the High Contracting Parties are bound to secure the said rights and freedoms to all persons under their actual authority and responsibility, whether that authority is exercised within their own territory or abroad. ${ }^{28}$

Even though Turkey had not extended civil, criminal or political authority to Northern Cyprus, its responsibility for violations of ECHR rights would stem from its actual control over the local population. Those individuals under Turkey's actual control would be within its jurisdiction, and Turkey would be obliged to secure their ECHR rights.

The Commission went on:

$[\mathrm{N}]$ ationals of a State, including registered ships and aircraft, are partly within its jurisdiction wherever they may be, and that authorised agents of a State, including diplomatic or consular agents and armed forces, not only remain under its jurisdiction when abroad but bring any other persons or property 'within the jurisdiction' of that State, to the extent that they exercise authority over such persons or property. In so far as, by their acts or omissions, they affect such persons or property, the responsibility of the State is engaged. ${ }^{29}$

The Commission makes it clear that individuals are within a state's jurisdiction for the purposes of the ECHR because of the control exercised over them by state agents, even where those agents are acting beyond the territory of their own state.

In the second of the Cyprus cases, the Commission approved of its earlier decision that persons and property are within the jurisdiction of a contracting state to the extent that the state exercises some control over them. ${ }^{30}$ By the time that case came before the Commission, Turkey had established the 'Turkish Federated State of Cyprus' as an independent state in the occupied territories. This state was unrecognised by the international community and it was not viewed

\footnotetext{
${ }^{27}$ Cyprus has made a number of applications to the ECHR bodies regarding the actions of Turkish authorities during the ongoing occupation of Cyprus: Cyprus v Turkey (No 1), Application no 6780/74, European Commission on Human Rights, Decision (26 May 1975), 2 Decisions \& Reports (1975) 125; Cyprus v Turkey (No 2) (n 21); Cyprus v Turkey (No 3), Application no 25781/94, European Commission on Human Rights, Decision (1 January 1997); Cyprus v Turkey (No 3), Application no 25781/94, European Court of Human Rights, Judgment (10 May 2001). For more detailed facts, see Cyprus v Turkey (No 1), 127-129.

${ }^{28}$ Cyprus v Turkey (No 1) (n 27) 136 (emphasis added).

${ }^{29}$ Ibid (emphasis added).

${ }^{30}$ Cyprus v Turkey (No 2) (n 21) para 63.
} 
by the Commission as an entity capable of exercising jurisdiction over any part of the island. ${ }^{31}$ Turkey's jurisdiction persisted, and it would be responsible for violations of the Convention imputable to it by virtue of the continued direct, physical control exercised by its soldiers in the occupied territories. It further implied that Turkish jurisdiction over individuals in the occupied Northern territories was exclusive, since Cyprus had 'been prevented from exercising its jurisdiction' there by virtue of the occupation. ${ }^{32}$

The Commission's decisions in the Cyprus cases clearly support the idea that jurisdiction for the purposes of IHRL is a concept quite distinct from that in PIL. But in reading their decision it is quite easy to muddle the two concepts. State agents acting abroad are under the orders of their state and are subject to their state's laws and enforcement mechanisms to varying degrees. By virtue of the occupation, Cyprus had indeed been prevented from enforcing its will over the Northern half of the island for the purposes of the PIL concept of jurisdiction. The Turkish Federated State of Cyprus did not possess jurisdiction for the purposes of the PIL concept because it was not a state (the capacity to enter into relations with other states being a prerequisite of statehood, ${ }^{33}$ which the Turkish Federated State lacked because it also lacked international recognition) and so did not have rights and duties vis-à-vis other states. But the Commission's decision should not be read as referring to the PIL concept of jurisdiction as the state's right to prescribe and enforce its will.

A more appropriate interpretation of the Commission's decision is that Cyprus had lost the ability to ensure the ECHR rights to the population of the occupied Northern territories because it had lost its physical and legal control over that population. State agents are within their own state's jurisdiction because of the control exercised over them. The Turkish Federated State was not capable of exercising jurisdiction over the population for the purposes of Article 1 because it was not a state party to the ECHR. ${ }^{34}$ The decisions did not concern the rights and duties of Cyprus and Turkey vis-à-vis each other and so the norms governing that relationship are of no application. The decisions were about the two states' obligations to the individuals under their control.

\footnotetext{
${ }^{31}$ Cyprus v Turkey (No 2) (n 21) para 63.

${ }^{32}$ Cyprus v Turkey (No 2) (n 21) para 63.

${ }^{33}$ Article 1(d), Montevideo Convention.

${ }^{34}$ It should be noted Turkey argued that the Turkish Federated State exercised jurisdiction over the occupied Northern territories to support its own claim that the local population were not subject to its own jurisdiction and that Turkey would not therefore be liable for any alleged violations of the ECHR. If the local population were subject to the jurisdiction of the Turkish Federated State, which was not a state party to the ECHR, any allegations of ECHR violations would go unanswered.
} 


\subsubsection{Other Cases Employing the Personal Model}

The Court and Commission have confirmed the Cyprus Commission's view in a number of subsequent cases. ${ }^{35}$ Although the facts of the various cases are conceptually different, the ECHR bodies have applied the same general principle to all; that individuals are within a state's jurisdiction by virtue of being under the authority and control of its agents. Individuals arrested by state agents abroad are within that state's jurisdiction from the moment they are taken into its agents' custody. ${ }^{36}$ The detaining state will be liable for any violations of Convention rights occurring during that custody, even though their agents are acting beyond their own territories, and even if they occur on the territory of another ECHR state party.

In the case of Medvedyev, a Cambodia-registered ship was intercepted on the high seas by a French naval vessel on suspicion of carrying narcotics. Upon boarding the vessel, French forces discovered a large quantity of drugs and confined the crew to quarters, setting a new course for France where the crew would be prosecuted. During their detention on the ship, the crew were within French jurisdiction for the purposes of Article 1, because France 'exercised full and exclusive control over the [ship] and its crew, at least de facto, from the time of its interception, in a continuous and uninterrupted manner'. ${ }^{37}$ The question for the Grand Chamber in Medvedyev was not whether the actions of the French forces were lawful for the purposes of France's obligations to Cambodia, but rather whether the Cambodian crew were under the actual physical control of the French naval forces. By virtue of that actual physical control, French forces were in a position to act in such a way that might constitute a violation of ECHR rights. It is this capacity to violate ECHR rights that constitutes jurisdiction for the purposes of IHRL.

In all of these cases, the state has enjoyed some direct physical control over the applicant in the form of detention. In the Cyprus cases, the mere presence of Turkish troops as occupying forces in the North of the island gave Turkey physical control over the local population. But the Court has judged that individuals can be within a state's jurisdiction even when they are not

\footnotetext{
${ }^{35}$ Wv Ireland, Application no 9360/81, European Commission on Human Rights, Decision (28 February 1983), 32 Decisions \& Reports (1983) 211, 215; Vearncombe v Germany and United Kingdom, Application no 12816/87, European Commission on Human Rights, Decision (18 January 1989), 59 Decisions \& Reports (1989) 186, 194.

${ }^{36}$ Freda v Italy, Application no 8916/80, European Commission on Human Rights, Decision (7 October 1980), 21 Decisions \& Reports (1980) 250, 256; Sánchez Ramirez v France, Application no 28780/95, European Commission on Human Rights, Decision (24 June 1996), 86 Decisions \& Reports (1996) 155, 162; Öcalan v Turkey, Application no 46221/99, European Court of Human Rights, Grand Chamber, Judgment (12 May 2005) para 91.

${ }^{37}$ Medvedyev v France, Application no 3394/03, European Court of Human Rights, Grand Chamber, Judgment (29 March 2010) para 67.
} 
held in custody. In another case involving the Turkish occupation of Cyprus, a Cypriot protester was beaten to death in the neutral UN-controlled buffer zone. Though he was not in their custody, he was subject to the Turkish forces' physical control and thus within Turkish jurisdiction for the purposes of Article $1 .{ }^{38}$ Similarly, where Kurdish shepherds were murdered in Northern Iraq, the Court judged that the shepherds would have been within Turkish jurisdiction had there been any physical evidence linking their deaths to Turkish soldiers. ${ }^{39}$

As well as direct physical control, the acts and omissions of diplomats and consular officials affecting the rights of individuals will bring those individuals within the relevant state's jurisdiction for the purposes of Article 1 of the ECHR. The Commission recognised this much earlier than the first Cyprus decision, ${ }^{40}$ in which the Commission merely clarified that the rule was still valid. The Commission has reiterated this position in subsequent cases involving allegations that British consular officials failed to return a kidnapped child from Jordan, ${ }^{41}$ and when the Danish ambassador to East Germany called the police to remove a group of wouldbe migrants from the embassy. ${ }^{42}$ The migrants were considered to be within Danish jurisdiction vis-à-vis the ambassador's actions, even though he was outside Denmark and the Commission did not consider the embassy to be part of Danish territory.

The Commission's decision in $M v$ Denmark is interesting, since it concerns individual rights that refer explicitly to territory. The applicants claimed that their right to move freely through Danish territory had been unlawfully infringed, ${ }^{43}$ and that they had been expelled from Denmark without due process of law. ${ }^{44}$ The Commission determined that the embassy was not part of Danish territory and so the applicants' rights under Protocols Nos 4 and 7 could not have been violated, whilst simultaneously finding that they were in fact within Danish jurisdiction for the purposes of their ECHR rights. This shows quite plainly how jurisdiction in IHRL is a different concept to that in PIL generally, which states the jurisdiction is primarily territorial. For a state to be held liable under the ECHR the relevant consideration in the personal model

\footnotetext{
${ }^{38}$ Isaak v Turkey, Application no 44587/98, European Court of Human Rights, Judgment (24 June 2008).

${ }^{39}$ Issa v Turkey, Application no 31821/96, European Court of Human Rights, Judgment (16 November 2004) para 79.

${ }^{40}$ Xv Germany, Application no 1611/62, European Commission on Human Rights, Decision (25 September 1965), 8 Yearbook of the European Convention on Human Rights (1965) 158, 168.

${ }^{41} X v$ United Kingdom, Application no 7547/76, European Commission on Human Rights, Decision (15 December 1977), 12 Decisions \& Reports (1977) 73, 74.

${ }^{42}$ Mv Denmark, Application no 17392/90, European Commission on Human Rights, Decision (14 October 1992).

${ }^{43}$ Protocol No 4 to the Convention for the Protection of Human Rights and Fundamental Freedoms, securing certain rights and freedoms other than those already included in the Convention and in the first Protocol thereto, as amended by Protocol No 11, 6 September 1963, in force 2 May 1968, ETS 46.

${ }^{44}$ Protocol No 7 to the Convention for the Protection of Human Rights and Fundamental Freedoms, as amended by Protocol No 11, 22 November 1984, in force 1 November 1988, ETS 117.
} 
is simply whether the agents of that state had control or authority over the individual, irrespective of where in the world that occurs.

The Commission and European Court have developed this personal model of jurisdiction to prevent an interpretation of Article 1 that would allow a 'State Party to perpetrate violations of the Convention on the territory of another State, which it could not perpetrate on its own territory'. ${ }^{45}$ The Court has quoted this passage verbatim from the views of the United Nations Committee on Human Rights. ${ }^{46}$ In a pair of cases, the Human Rights Committee was asked to evaluate whether Uruguay had violated ICCPR provisions by sending security forces to arrest and hold suspects in incommunicado detention in Argentina and Brazil, before transferring them back to Uruguay for trial. The applicants in those cases were entitled to the protections of the ICCPR against Uruguay, due to being under the state agents' physical control.

The personal model is highly individualistic, the state's physical or legal control over an individual being the nexus establishing the obligation. ${ }^{47}$ The essence of the personal model is that an individual is within the state's jurisdiction where the state's actions affect his ability to exercise his ECHR rights. ${ }^{48}$ Whilst IHRL is found in multilateral treaties that create mutual and collective enforcement obligations on states parties, the primary obligation in these treaties is not to other states, but to individuals. Where human rights are predicated on the assumption that all human beings are equal and that the rights contained in the treaties are inherent to all people, ${ }^{49}$ it would be absurd for a state to have obligations to individuals within its own territory but not to those outside its territory but nevertheless subject to its physical control. The personal model arguably recognises that states possess enormous coercive power over individuals and that power is not necessarily limited to a state's territory.

There is a link between the two concepts of jurisdiction in PIL and IHRL. When an individual is 'brought within the jurisdiction' of a state for the purposes of IHRL by virtue of being under state agent authority and control, the actions of the state constitute an exercise of jurisdiction in the PIL sense. In Medvedyev, when French naval forces arrested the ship's crew and transported them back to France to stand trial for drugs offences, they were exercising

\footnotetext{
${ }^{45}$ Issa (n 39) para 71.

${ }^{46}$ López Burgos v Uruguay, Communication no R.12/52, Human Rights Committee, Views (6 June 1979), UN Doc Supp No 40 (A/36/40) (1981) 176, para 12.8; Celiberti de Casariego v Uruguay, Communication no 56/1979, UN Doc CCPR/C/OP/1 (1984) 92, para 10.3.

${ }^{47}$ Françoise Hampson, 'Using International Human Rights Machinery to Enforce the International Law of Armed Conflicts' (1992) 31 Revue de Droit Militaire et de Droit de la Guerre 119-47, 122.

${ }^{48}$ Sarah Miller, 'Revisiting Extraterritorial Jurisdiction: A Territorial Justification for Extraterritorial Jurisdiction under the European Convention' (2009) 20 (4) European Journal of International Law 1223-46, 1223.

${ }^{49}$ See for example Preamble, ICCPR; Preamble, ACHR.
} 
France's power (normally constrained to its national territory) to impose its law, beyond French territory. In Öcalan, the Turkish police officers who arrested Öcalan in Kenya were exercising Turkey's power (normally constrained to its national territory) to arrest those suspected of violating national law, outside Turkey. In all the cases in which the personal model has been applied, state agents have acted in a way that can be considered an exercise of PIL jurisdiction. PIL jurisdiction determines whether that action was lawful considering states' duties to one another and the obligation to uphold the sovereign equality of states. But IHRL jurisdiction does not depend upon the exercise of the state's power being lawful for the purposes of PIL. The personal model is only the first of two models of jurisdiction recognised by the European Court. The second approach contains a much stronger link to territory.

\subsection{Spatial Model}

\subsubsection{Loizidou v Turkey}

In Loizidou, the applicant was denied access to her property in Turkish-controlled Northern Cyprus and had been detained by Turkish soldiers and Turkish-Cypriot police in the course of a peaceful demonstration. ${ }^{50}$ She alleged numerous violations of her ECHR rights regarding property and detention. The Court repeated the principle that the Convention is not limited to the contracting states' national territories. Individuals in a foreign territory under the state's effective control will also be within its jurisdiction.

Bearing in mind the object and purpose of the Convention, the responsibility of a Contracting Party may also arise when as a consequence of military action - whether lawful or unlawful it exercises control of an area outside its national territory. The obligation to secure, in such an area, the rights and freedoms set out in the Convention derives from the fact of such control whether it be exercised directly, through its armed forces, or through a subordinate local administration. ${ }^{51}$

Through its military occupation in Northern Cyprus, Turkey had effective control of that territory. Effective control is a question of fact that will depend upon all the circumstances. There is no specific legal threshold that must be reached in order for a state to have effective control over territory. In Loizidou, the sheer number of troops on the ground and the duration of the occupation were sufficient to establish Turkey's effective control, even though it did not directly administer the territory as part of Turkey. ${ }^{52}$ Furthermore, the 'Turkish Republic of Northern Cyprus', a unilaterally-declared sovereign state in Northern Cyprus, relied upon

\footnotetext{
${ }^{50}$ For more detailed facts, see Loizidou (n 24) paras 10-14.

${ }^{51}$ Loizidou (n 24) para 62 (emphasis added).

${ }^{52}$ Loizidou (n 24) para 62.
} 
Turkish military presence for its survival. ${ }^{53}$ It was thus a subordinate local administration and individuals under their nominal authority would be within Turkish jurisdiction. Turkey's lack of detailed control or involvement in the administration's policy was irrelevant. ${ }^{54}$ In spite of not having control over the Turkish Republic of Northern Cyprus' governmental functions, events within Northern Cyprus occurred under Turkish control.

In PIL, the effective control doctrine is more concerned with attribution of conduct to a state for determining that state's liability for acts violating international law. Under the effective control doctrine, an individual's conduct is attributable to the state if that state had effective control of the individual at the material time. The International Court of Justice used the effective control test in the Nicaragua case, ${ }^{55}$ concerning United States' support of the contras rebel group in Nicaragua. The degree of control exercised by the US Government over the contras' activities would determine whether the group's actions were attributable to the US for the purposes of liability for a violation of PIL. ${ }^{56}$ Although the contras were dependent upon US support for their activities, ${ }^{57}$ the Court was not persuaded by the evidence before it that the US exerted sufficient control over the contras to be held liable for their actions. ${ }^{58}$ Similarly, the International Criminal Tribunal for the Former Yugoslavia ('ICTY') considered Yugoslavia's control over the Bosnian Serb Army for the purposes of determining the state's responsibility for the crimes for which it stood accused during the Bosnian War. ${ }^{59}$ Whilst distinguishing the events of the Bosnian War from those in the Nicaragua case, the ICTY applied a similar test and concluded that Yugoslavia exercised sufficient effective control over the Bosnian Serb Army for the acts of the latter to be attributed to it. ${ }^{60}$ The European Court's approach to effective control signals yet another departure from PIL.

\subsubsection{Other Cases Employing the Spatial Model}

The European Court repeated its principles in response to Transdniestrian separatists in Moldova. Both Moldova and Russia are states parties to the ECHR. Russian military and

\footnotetext{
${ }^{53}$ Cyprus v Turkey (No 2) (n 21) para 17.

${ }^{54}$ Loizidou v Turkey (Merits), Application no 15318/89, European Court of Human Rights, Grand Chamber, Judgment (18 December 1996) para 56.

${ }^{55}$ Case Concerning Military and Paramilitary Activities in and against Nicaragua (Nicaragua v United States of America), Merits, International Court of Justice, Judgment, 27 June 1986, ICJ Reports 1986, 14.

56 Ibid, para 113.

57 Ibid, para 110.

${ }^{58}$ Ibid, para 115.

${ }^{59}$ Prosecutor v Duško Tadić, Case no IT-94-I-T, International Criminal Tribunal for the Former Yugoslavia, Judgment, 7 May 1997.

${ }^{60}$ Ibid, para 595.
} 
political support greatly strengthened the 'Moldovan Republic of Transdniestria', which had unilaterally declared independence from Moldova. ${ }^{61}$ Though not dependent upon Russian support for its survival, the separatist entity was under Russia's decisive influence. ${ }^{62}$ Individuals within Transdniestria were within Russian jurisdiction, and Russia was under the obligation to secure ECHR rights to those individuals. ${ }^{63}$ As in all the human rights jurisdiction cases, this spatial model of jurisdiction is not concerned with where states are permitted to exercise the powers conferred by statehood, but when and where their ECHR obligations are engaged.

The European Court has not restricted itself to finding jurisdiction when states have control over the whole of another state's territory, or even large swathes of it like in Loizidou and Ilaşcu. The Court stated that the presence of troops in an area gives the state effective control over the area in which they are active, but not the whole territory of the state. ${ }^{64}$ Aerial military action, however, does not establish effective control of a territory without a simultaneous ground-based military presence. ${ }^{65}$ An occupation of longer duration may give control over a wider area, although this will depend upon the facts of the case. In a number of cases, the Court has recognised that control over a building will suffice the cross the threshold and establish that those inside the building are within the state's jurisdiction, by virtue of the state's 'total, exclusive de facto' control of the premises. ${ }^{66}$

\subsection{Confusion and Clarification}

For many years the personal and spatial models of control co-existed in relative harmony, in spite of some degree of uncertainty over which might be applied where. Typically the personal model was employed in cases like Freda, Vearncombe and Sánchez Ramirez, ${ }^{67}$ where the spatial model could not apply but it would be inconsistent with the object and purpose of the ECHR to deny the applicants any rights against the respondent states. The European Court then gave its decision as to the admissibility of Banković, which confused the matter. The decision was solely based on the spatial model of jurisdiction, with the Court's Grand Chamber omitting

\footnotetext{
${ }^{61} \mathrm{Ilașcu}$ (n 18) para 382. For more detailed facts, see paras 28-110.

${ }^{62} \mathrm{Ilașcu}$ (n 18) para 392.

${ }^{63} \mathrm{Ilaşcu}$ (n 18) para 392.

${ }^{64}$ Issa (n 39) paras 74-75.

${ }^{65}$ Banković and others $v$ Belgium and others (Admissibility), Application no 52207/99, European Court of Human Rights, Grand Chamber, Decision (22 December 2001) para 75.

${ }^{66}$ Al-Saadoon and Mufdhi v. United Kingdom, Application no. 61498/08, European Court of Human Rights, Judgment (30 June 2009), para. 88

${ }^{67}$ Freda (n 36), Vearncombe (n 35), Sánchez Ramirez (n 36).
} 
to mention the personal model ${ }^{68}$ Yet the personal model continued to be applied in other later cases (Öcalan, Issa and Medvedyev ${ }^{69}$ being noted examples). A decade of confusion was cleared up (at least in part) when the Grand Chamber gave its judgment in Al-Skeini.

\subsubsection{Banković v Belgium}

In a NATO bombing raid on Belgrade, 16 civilians were killed when a missile hit a television station. ${ }^{70}$ Those injured and the deceased's next of kin began proceedings before the European Court against those states that participated in the raid. In its admissibility decision, the Court stated that the jurisdictional competence of states is 'primarily territorial'. ${ }^{71}$ Any other bases of jurisdiction, beyond those recognised in customary international law and treaty provisions (such as the acts of consular and diplomatic officials) would be 'exceptional and [require] special justification'. ${ }^{72}$ The Court agreed with the respondent governments that the facts of this case did not fall within any of those special justifications and to rule otherwise would be

[T]antamount to arguing that anyone adversely affected by an act imputable to a Contracting State, wherever in the world that act may have been committed or its consequences felt, is thereby brought within the jurisdiction of that State. ${ }^{73}$

The Court noted the principles in the case law that extraterritorial jurisdiction would be recognised

[W] hen the respondent State, through the effective control of the relevant territory and its inhabitants abroad as a consequence of military occupation or through the consent, invitation or acquiescence of the Government of that territory, exercises all or some of the public powers normally to be exercised by that Government. ${ }^{74}$

The need for the exercise of executive authority was required because of the Court's judgment that the Convention rights cannot be 'divided and tailored' and that the positive obligation to secure them is only engaged when the state is in a position to secure them en bloc. ${ }^{75}$

Although the principle that the state's Convention obligations are not limited to its own territory had been repeated in case law, the Banković Court also noted that the Convention is a 'multi-lateral treaty operating ... in an essentially regional context' and that it would not apply

\footnotetext{
${ }^{68}$ Banković (n 65) para 75.

${ }^{69}$ Öcalan (n 36), Issa (n 39), Medvedyev (n 37).

${ }^{70}$ For more detailed facts, see Banković (n 65) paras 6-11.

${ }^{71}$ Banković (n 65) para 59.

${ }^{72}$ Banković (n 65) para 61.

${ }^{73}$ Banković (n 65) para 75.

${ }^{74}$ Banković (n 65) para 71 (emphasis added).

${ }^{75}$ Banković (n 65) para 75.
} 
outside the legal space of the Council of Europe territories. ${ }^{76}$ Turkey's jurisdiction in Loizidou and the other Northern Cyprus cases was rationalised on the basis that the occupied territories remained part of Cypriot sovereign territory. They form part of the espace juridique of the Council of Europe, territories which would ordinarily be covered by the Convention. ${ }^{77}$ The Federal Republic of Yugoslavia was not a member of the Council of Europe and therefore its citizens were not entitled to ECHR protections.

Academics have strongly criticised the Banković judgment for its dubious PIL references to the detriment of the object and purpose of the ECHR and for unnaturally limiting the ECHR's application to the territories of states parties. ${ }^{78}$ The Banković Court adopted a restrictive interpretation of jurisdiction resembling some of the doctrinal elements of jurisdiction in PIL, including the strong relationship to territory that limits a state's legal right to 'impose its will'. ${ }^{79}$ Although not free from criticism, some of the Court's reasoning is sound. Many of the rights in the ECHR impose negative and positive obligations on states. The Court is correct that a state must exercise some governmental functions in a territory to be able to put in place the mechanisms and systems to fulfil the positive obligation to individuals within that territory. For instance, in relation to the right to life, ${ }^{80}$ the European Court has judged that states are under the positive obligation to enact a domestic legal framework to criminalise the intentional deprivation of life. ${ }^{81}$ Where a state is acting in another territory but does not exercise any governmental functions in respect of that territory, it cannot be expected to put such a framework in place in pursuit of its positive ECHR obligations. But it would be quite wrong to apply that reasoning to the negative obligation. The negative obligation imparted under Article 2 requires state agents to refrain from killing intentionally. States do not need to exercise any control over territory to prevent their agents from pulling the trigger, as they exercise control over those agents wherever they are in the world and are therefore in a position to affect

\footnotetext{
${ }^{76}$ Banković (n 65) para 80.

${ }^{77}$ Banković (n 65) para 80.

${ }^{78}$ See Alexander Orakhelshvili, 'Restrictive Interpretation of Human Rights Treaties in the Recent Jurisprudence of the European Court of Human Rights' (2003) 14 (3) European Journal of International Law 529-68; Milanović (n 25); Erik Roxstrum, Mark Gibson and Terje Einarsen, 'The NATO Bombing Case (Banković et al. v. Belgium et al.) and the Limits of Western Human Rights Protection' (2005) 23 Boston University International Law Journal 55-136; Loukis G Loucaides, 'Determining the Extra-Territorial Effect of the European Convention: Facts, Jurisprudence and the Banković Case' (2006) 4 European Human Rights Law Review 391-407.

${ }^{79}$ Loucaides, ibid, 399.

${ }^{80}$ Article 2, ECHR.

${ }^{81}$ Robin CA White and Claire Ovey (eds), Jacobs, White and Ovey: The European Convention on Human Rights, 5th edn (Oxford, Oxford University Press, 2010) 152; Osman v United Kingdom, Application no 23452/94, European Court of Human Rights, Grand Chamber, Judgment (28 October 1998) para 116; Kllıç v Turkey, Application no 22492/93, European Court of Human Rights, Judgment (28 March 2000) para 62; Kaya v Turkey, Application no 22535/93, European Court of Human Rights, Judgment (28 March 2000) para 85.
} 
individuals' rights, since it is through the actions and omissions of its agents that states exercise control over those individuals. The judgment in Banković was arguably misguided.

The Banković judgment was 'inevitably politically charged'. ${ }^{82}$ Eight weeks before the Court handed down its judgment, a United States-led coalition invaded Afghanistan. The Court's interpretation of jurisdiction in Banković might prevent the application of the ECHR to the Afghanistan conflict, since at the time of the judgment the invading coalition did not have effective control of the country. Whilst such control might have solidified later, and the invading forces might have come to exercise some governmental functions, in making its judgment the Court was arguably conscious of limiting potential cases to come out of the conflict. In spite of this, a state's international obligations under the ECHR should not be restricted by reference to the legal limits of the state's domestic law. ${ }^{83}$ Jurisdiction in PIL is a formalistic concept determining where and in what circumstances a state can impose its will, whether that be its civil, criminal, constitutional, or any other body of law. Jurisdiction in IHRL, however, is 'discerned from a factual scenario which arises by virtue of circumstance'. ${ }^{84}$ Whether an individual's human rights under the ECHR, or any other international human rights instrument, have been violated does not depend upon the legal limits of a state's domestic authority. It is a question of fact. The Banković Court strayed from this line of reasoning.

One of the problems with the ruling in Bankovic is that the Court does not seek to define 'territory'. The Court had in previous cases accepted control of a building as effective control of territory such as to bring the individuals therein detained within the controlling state's jurisdiction. The question then becomes whether there is a minimum area over which control must be exercised. Would control of a single room in the building count? Or the area of ground in which the state agent stands? At this point, the spatial model seems to collapse into the personal model. It is far easier to accept that an individual is within a state's jurisdiction because he is personally within the control of that state's agents than it is to accept that state's jurisdiction applied because of control of a particular square-footage. The Court offered some remedy to this problem by introducing the requirement that the state exercise governmental functions over the territory. But this is also poorly defined, and the ability of state agents to

\footnotetext{
${ }^{82}$ Max Schaefer, 'Al-Skeini and the Elusive Parameters of Extraterritorial Jurisdiction' (2011) 5 European Human Rights Law Review 566-81, 569.

${ }^{83}$ These limits are well-discussed in Michael Akehurst, 'Jurisdiction in International Law' (1972-73) 46 British Yearbook of International Law 145-257; Lowe and Staker, 'Jurisdiction’ in Evans (n 1) 313-39; Malcolm N Shaw, International Law, 6th edn (Cambridge, Cambridge University Press, 2008) 645-96.

${ }^{84}$ Conall Mallory, 'European Court of Human Rights Al-Skeini and Others v. United Kingdom (Application no. 55721/07) Judgment of 7 July 2011' (2013) 61(1) International Comparative Law Quarterly 301-12, 310.
} 
violate individual rights is not parasitic on the exercise of governmental functions over a territory.

\subsubsection{Al-Skeini v United Kingdom}

Ten years after Banković, the Grand Chamber handed down its judgment in Al-Skeini v United Kingdom. During the US-UK military operations in Iraq, British troops had killed five Iraqi nationals whilst on patrol in Basra City. A sixth individual, Baha Mousa, died in security detention in a British military prison. The British Government conceded that Baha Mousa was within British jurisdiction by virtue of exclusive British control of the detention premises. The British House of Lords, following Banković, ruled that the first five individuals were not within British jurisdiction at the time of their deaths for two reasons. First, because as a regional treaty the ECHR could not apply outside the territories of the Council of Europe, and second because the UK did not have effective control of Basra. ${ }^{85}$

In its judgment, the European Court's Grand Chamber repeated the principle that states' jurisdiction is primarily territorial and that jurisdiction is normally exercised throughout a state's national territory. ${ }^{86}$ But the Grand Chamber detailed the 'exceptional circumstances capable of giving rise to the exercise of jurisdiction by a contracting state outside its own boundaries' ${ }^{87}$ The first is the 'very broad principle' that

[A] Contracting State's jurisdiction under Article 1 may extend to acts of its authorities which produce effects outside its own territory. ${ }^{88}$

The Court affirmed that 'the use of force by a State's agents operating outside its territory may bring the individual thereby brought under the control of the State's authorities into the State's Article 1 jurisdiction' ${ }^{89}$ The Court expressed the opinion that in cases where state agents, acting outside the state's territory, held an individual in custody, jurisdiction did not arise because of the state's control of the detention premises or vessel; 'What is decisive in such cases in the exercise of physical power and control over the person in question.${ }^{90}$ In a situation where a

\footnotetext{
${ }^{85} R$ (Al-Skeini) v Secretary of State for Defence (2007) UKHL 26, (2008) 1 AC 153, (83) (Lord Rodger); (97) (Lord Carswell); (132) (Lord Brown).

${ }^{86}$ Al-Skeini v United Kingdom, Application no 55721/07, European Court of Human Rights, Grand Chamber, Judgment (7 July 2011) para 131.

${ }^{87} \mathrm{Ibid}$, para 132.

${ }^{88}$ Ibid, para 133, quoting Drozd and Janousek (n 26) para 91; Loizidou (Preliminary Objections) (n 24) para 62; Loizidou (Merits) (n 54) para 52; Banković (n 65) para 69.

${ }^{89}$ Al-Skeini (n 86) para 136.

${ }^{90}$ Al-Skeini (n 86) para 136 (emphasis added).
} 
state exercises physical power and control over an individual, the Article 1 obligation to extends to 'the rights and freedoms under Section I of the Convention that are relevant to the situation of that individual', ${ }^{91}$ but not necessarily all of the ECHR rights.

In its judgment, the Court said that individuals may be within the state's jurisdiction abroad when, with the consent, invitation or acquiescence of the territorial government, it exercises some of the public powers normally be exercised by that government. ${ }^{92}$ The Court referred to its earlier decision in Banković, and although the Banković Court rejected the 'causeand-effect' notion of jurisdiction for single instantaneous acts - such as dropping a missile or firing a gun - the Court clarified in Al-Skeini that the individuals affected by such acts would be within the state's jurisdiction where the state is also exercising public powers. ${ }^{93}$ This is a somewhat disappointing turn by the Court. Although it goes on to say that those under the direct physical control of state agents are within the jurisdiction of that state, ${ }^{94}$ this creates a lacuna in the law according to which it would be permissible for a soldier acting outside the territory of his own state to attack an individual with a long-range weapon, and the victim would have no enforceable right against the soldier's state.

Several scholars have remarked that the Court's judgment is an odd fusion of the personal and spatial models, with individuals being within the state's jurisdiction when, through the exercise of public powers, it has control and authority over them. ${ }^{95}$ But that is a misreading of the Court's general principles of extraterritorial jurisdiction. The reference to public powers arguably pays lip-service to Banković, but jurisdiction does not arise solely from the exercise of public powers. The exercise of the public powers model, detailed in paragraph 135 of the Court's judgment, is one discrete form of personal control, as evidenced by the Court numbering this separately from other options of authority and control. The Court also confirmed that the Article 1 obligation will be engaged when, as a consequence of military action (whether or not that action is lawful), a state exercises effective control of a territory, either directly, through its armed forces, or through a subordinate local administration. ${ }^{96}$ Unlike the personal model, the obligation under the effective control of territory doctrine requires the state to secure all the Convention rights. ${ }^{97}$ The fact that a subordinate local administration survives by virtue

\footnotetext{
${ }^{91}$ Al-Skeini (n 86) para 137 (emphasis added).

${ }^{92}$ Al-Skeini (n 86) para 135.

93 Marko Milanović, 'European Court decides Al-Skeini and Al-Jedda', EJIL:talk!, 7 July 2011, <www.ejiltalk.org/european-court-decides-al-skeini-and-al-jedda/> (accessed 19 June 2014).

${ }^{94}$ Al-Skeini (n 86) para 136.

${ }^{95}$ Paolo Ronchi, ‘The Borders of Human Rights' (2012) 128 (Jan) Law Quarterly Review 20-23, 22.

${ }^{96}$ Al-Skeini (n 86) para 138, citing Loizidou (Preliminary Objections) (n 24) para 62.

${ }^{97}$ Al-Skeini (n 86) para 138.
} 
of a state's support will engage the Article 1 obligation in respect of that territory, whether or not the state is actively involved in policy-making. ${ }^{98}$

Effective control of territory is a question of fact. ${ }^{99}$ The Court may have regard of the strength of the state's military presence in the area, ${ }^{100}$ as well as other indicators such as the extent to which the military, political and economic support bolsters the local administration. ${ }^{101}$ Territories under a state's effective control are not analogous to 'territories for whose international relations it is responsible', ${ }^{102}$ and Article 56 of the Convention cannot be used to exclude the state's Convention responsibilities in occupied territories (which have a different status in international law than colonies and dependencies). ${ }^{103}$ The Court made reference to the espace juridique principle, repeating that the Convention cannot bind states not parties to it, ${ }^{104}$ and that it is a constitutional instrument of European public order. ${ }^{105}$ It affirmed that where the armed forces of a Convention state occupy the territory of another Convention state, the occupying state is bound by the Convention so as to prevent a 'regrettable vacuum' within the Convention legal space. ${ }^{106}$ It clarified, though, that this rule does not prevent application of the Convention beyond Council of Europe Member States' territories, and that it had never applied such a restriction in its case law. ${ }^{107}$ Though the Convention is of 'essentially regional vocation', ${ }^{108}$ that should not be understood as 'exclusively regional vocation' ${ }^{109}$

It has been argued that Banković was wrongly interpreted by the British judiciary, and that that judgment did nothing more than exclude aerial bombardment from the list of actions giving rise to effective control. ${ }^{110}$ Whether or not this is correct, the espace juridique principle can no longer be a realistic argument that states are not bound by the Convention beyond the Council of Europe's borders, or that jurisdiction in IHRL is the same as jurisdiction in PIL. The judgment in Al-Skeini seems to lack any principled reasoning or attempt to rationalise the diverse list of discrete conditions for jurisdiction. Instead, it is a mere restatement (with some

\footnotetext{
${ }^{98}$ Al-Skeini (n 86) para 138.

${ }^{99}$ Al-Skeini (n 86), para 139.

${ }^{100}$ Al-Skeini (n 86), para 139, citing Loizidou (Merits) (n 54) paras 16 and 56; Ilașcu (n 18) para 387.

${ }^{101}$ Al-Skeini (n 86), para 139, citing Ilașcu (n 18) paras 388-94.

102 Article 56(1), ECHR.

${ }^{103}$ Al-Skeini (n 86) para 140.

${ }^{104}$ Al-Skeini (n 86) para 141, citing Soering (n 11) para 86.

${ }^{105}$ Al-Skeini (n 86), citing Loizidou (Preliminary Objections) (n 24) para 75.

${ }^{106}$ Al-Skeini (n 86) para 142, citing Banković (n 65) para 80.

${ }_{107}$ Al-Skeini (n 86) para 142, citing Öcalan (n 36), Issa (n 39), Al-Saadoon (n 66), Medvedyev (n 37).

108 Banković (n 65) para 80.

${ }^{109}$ Angelika Nußberger, 'The Concept of Jurisdiction in the Jurisprudence of the European Court of Human Rights' (2012) 65 Current Legal Problems 241-68, 266.

110 Joanne Williams, 'Al-Skeini: A Flawed Interpretation of Banković' (2005) 23 Wisconsin International Law Journal 687-729, 688.
} 
modifications or clarifications) of what the Court had said in previous cases. The Grand Chamber had the opportunity to thoroughly reject Bankovic and ensure that where states exercise physical control over an individual that individual is within its jurisdiction. Al-Skeini represented a chance for the Grand Chamber to properly consider the decades of Article 1 jurisprudence and think out a principled approach to what jurisdiction actually means, but the opportunity was missed.

Ultimately, the Al-Skeini Court ruled that there is nothing in its case law or the Convention itself that restricts the scope of states' obligations to their own territories, or even to territories within the espace juridique of the Council of Europe. Those obligations bind states in their actions overseas as well. Both the personal and spatial models of jurisdiction are applicable and relevant to determining to whom states owe ECHR obligations. In Al-Skeini, the United Kingdom,

[T]hrough its troops engaged in security operations in Basra during the period in question, exercised authority and control over individuals killed in the course of such security operations, such as to establish a jurisdictional link between the United Kingdom and the deceased for the purposes of Article 1 of the Convention. ${ }^{111}$

The Court did not examine whether the UK had effective control of the territory, and resolved the issue resorting exclusively to the personal model.

The judgment in Al-Skeini is not a panacea for the confusion caused by different interpretations of jurisdiction adopted in the Court's earlier case law. But in some measure it has undone some of the 'residual confusion' of the personal model being applied after the Banković judgment. ${ }^{12}$ The tenor of the Al-Skeini judgment is that 'control entails responsibility', ${ }^{113}$ although some have suggested Banković would not be decided any differently today. ${ }^{114}$ The judgment in Al-Skeini has come on a 'need-to-decide basis', ${ }^{115}$ but it confirmed that state agent authority and control is a viable and legitimate model for determining if states owe given individual obligations under the ECHR. It is not, as some have suggested, merely

\footnotetext{
111 Al-Skeini (n 86) para 149.

112 Anna Cowan, 'A New Watershed? Re-evaluating Banković in Light of Al-Skeini' (2012) 1 (1) Cambridge Journal of International and Comparative Law 213-27, 227.

${ }^{113}$ Marek Szydło, 'Extra-Territorial Application of the European Convention on Human Rights After Al-Skeini and Al-Jedda' (2012) 12 International Criminal Law Review 271-91, 291.

114 Cowan (n 112) 225.

115 Alasdair Henserson, 'War, Power and Control: The Problem of Jurisdiction', UK Human Rights Blog, 14 July 2011, <ukhumanrightsblog.com/2011/07/14/war-power-and-control-the-problem-of-jurisdiction> (last visited 18 July 2017).
} 
'territorial-lite'. ${ }^{116}$ It is clear, however, from the Court's ruling in Al-Skeini, that a narrow interpretation of Article 1 is untenable given states' ability to project their power globally and to impact individuals' rights in territories that they do not control. ${ }^{117}$ The Al-Skeini judgment is not really a change of tack, since the Court had adopted the personal model of jurisdiction even after the Grand Chamber's Banković judgment. Rather it is a response to misinterpretations of the Court's jurisprudence by national courts and academics. Though the Banković judgment appeared authoritative on the meaning of jurisdiction because it was a Grand Chamber judgment, it only set out the meaning of jurisdiction as it related to the facts of that case, rather than an exhaustive and definitive list of when individuals are within a state's jurisdiction for the purposes of Article 1.

\section{Soldiers before the Supreme Court}

The principles and rules established in the European Court's case law have been developed in cases where individuals have been affected by the extraterritorial acts of state agents. The Commission in Cyprus said that authorised agents of the state remain within the state's jurisdiction when abroad, but it has never affirmed that this is the case when the agents are the victims of alleged violations - only when they are the alleged perpetrators. The European Court was recently seized of a case of a British soldier killed on active service in Iraq, but a friendly settlement was reached between the applicant and the British Government before the European Court came to consider the case. ${ }^{118}$ As such, the European Court has never examined whether soldiers, who by virtue of being authorised by their state bring individuals over whom they have authority and control into their state's jurisdiction, are also within the state's jurisdiction for the purposes of human rights violations they suffer.

The UKSC has grappled with this issue twice, relating to the Convention rights of British soldiers serving abroad. In applying the Court's jurisprudence, the UKSC has been mindful that the Convention bodies have never been faced with similar facts, and that its

\footnotetext{
${ }^{116}$ Cedric Ryngaert, 'Clarifying the Extraterritorial Application of the European Convention on Human Rights' (2012) 28 (74) Utrecht Journal of International and European Law 57-60, 59.

${ }^{117}$ Olivier de Schutter, 'Globalization and Jurisdiction: Lessons from the European Convention of Human Rights' (2006) 6(1) Baltic Yearbook of International Law 185-247, 186.

${ }_{118}$ Pritchard v United Kingdom, Application no 1573/11, European Court of Human Rights, Decision (18 March 2014).
} 
judgments must be based on the general principles established by the Court. ${ }^{119}$ The UKSC came to different conclusions regarding jurisdiction in the two cases, but the European Court's judgment in Al-Skeini was handed down in the period between them.

\section{1. $R$ (on the application of Smith) $v$ Secretary of State for Defence}

\subsubsection{Facts and Appellate History}

In March 2003, US forces in coalition with contingents from the UK, Poland, Australia and other nations launched an invasion of Iraq. Following the ouster of Saddam Hussein and his Ba'ath party the victorious allies established the Coalition Provisional Authority ('the CPA'), which was later recognised as the sovereign government of Iraq. ${ }^{120}$ Coalition forces remained in Iraq as occupying powers until the CPA handed power to the Iraqi Interim Government in June 2004. From then, those forces remained in Iraq at the request of the new government, to assist with peace-keeping and reconstruction. The last British forces withdrew in 2011.

Private Smith was a British soldier deployed to Iraq and stationed in Basra. He was found collapsed in a doorway and rushed to the military hospital on the British base. He later died of heatstroke. His mother claimed that procedural irregularities in the coroner's inquest into Smith's death constituted a violation of his right to life under Article 2 of the ECHR. The primary question for this appeal was whether the ECHR applied to Smith at all at the time of his death, since he was on active service outside the UK and outside the espace juridique of the Council of Europe. The British Government conceded that its jurisdiction extended to the military base abroad on the basis of the spatial model of jurisdiction, but contended that its obligation to protect ECHR rights ended as soon as soldiers stepped off-base.

In the High Court, Collins J ruled that Smith was within the UK's jurisdiction and enjoyed his ECHR rights at the time of his death. ${ }^{121}$ In the Court of Appeal, Sir Anthony Clarke MR, Keene and Dyson LJJ affirmed the judge's ruling. ${ }^{122}$ The judges held that soldiers are always within the state's jurisdiction, even when on active service abroad and outside the

\footnotetext{
119 Smith (No 2) (n 10) (42) (Lord Hope DP).

${ }^{120}$ UNSC Res 1483 (22 May 2003) UN Doc S/RES/1483.

${ }^{121} R$ (Smith) v Secretary of State for Defence and Another (2008) EWHC 694 (Admin), (2008) 3 WLR 1284, (14)(20).

${ }^{122} R$ (Smith) v Secretary of State for Defence and Another (2009) EWCA Civ 441, (2009) 3 WLR 1099, (29) (Sir Anthony Clarke MR).
} 
military base. The Government lodged a final appeal to the UKSC. Nine justices sat in judgment, delivering a 6-3 majority verdict in the Government's favour. The state's jurisdiction, they said, is territorial and ends at the walls of the base.

\subsubsection{Lord Collins SCJ}

Lord Collins SCJ gave the leading judgment. He decided the case on the basis of the territorial model of jurisdiction, citing Banković. At the time of Smith's death, the UK had been responsible for the four south-easternmost of Iraq's eighteen governorates, where 8,000 troops were responsible for a population of almost three million, spread over roughly 40,000 square miles. Remembering that effective control of an area is a question of fact, established inter alia by the number of troops in the territory and the duration of the control, Lord Collins was not satisfied that the UK could have had effective control of the area under its responsibility at the time of Smith's death. ${ }^{123}$ The European Court has never come up with a golden ratio of troops required to establish control, but to put the numbers in perspective, in Loizidou 40,000 Turkish troops were stationed in Northern Cyprus, an area of around 1,250 square miles and a population of almost 300,000 . This suggests that there is a minimum ratio of troops to territory and population to establish effective control. Lord Collins did not elaborate on whether he had considered other factors in his estimation, such as the degree of hostility towards the occupying troops.

Lord Collins mentioned the references to PIL in Banković, which affirmed that states may exercise jurisdiction extraterritorially at the consent, invitation or acquiescence of the territorial state. ${ }^{124}$ Lord Collins considered that British forces could not have been exercising jurisdiction on these grounds at the relevant time, since the UK was a belligerent occupant at the relevant time. ${ }^{125}$ Furthermore, since all legislative and executive power was vested in the CPA (in whose decision-making processes the UK had no substantive role) the UK could not be said to be exercising governmental functions in respect of the territory as required by Banković. ${ }^{126}$

Lord Collins went on to observe that the Commission's ruling in Cyprus (No 1) that extraterritorial acts or omissions could bring individuals within the state's jurisdiction is

\footnotetext{
${ }^{123}$ Smith (No 1) (n 9) (232).

${ }^{124}$ Established in $X$ and $Y v$ Switzerland, Applications nos 7289/75 and 7349/79, European Commission on Human Rights, Decision (14 July 1977), 9 Decisions \& Reports (1977) 57, 71.

${ }^{125}$ Smith (No 1) (n 9) (232).

${ }^{126}$ Smith (No 1) (n 9) (227), citing Banković (n 65) para 71.
} 
inconsistent with the text of Article 1, which refers to individuals being within the state's jurisdiction, rather than acts. ${ }^{127}$ The personal model, Lord Collins said, is without foundation in the Court's case law and inconsistent with the Bankovic rule that jurisdiction is primarily territorial. Furthermore, it is dissonant with the concept of the ECHR as an instrument of European public order operating in a regional context. ${ }^{128}$ His Lordship made reference ${ }^{129}$ to the European Court's Marković judgment that an individual need not be in the territory of a state for the existence of a 'jurisdictional link', ${ }^{130}$ but rejected the argument that this created a basis of jurisdiction separate to those confirmed in Banković. ${ }^{131}$

Lord Collins rationalised the European Court's use of the personal model on the basis that many of the cases in which it was applied involved individuals detained by state agents acting abroad in anticipation of rendition to and trial within that state's territory. In Öcalan, for instance, the applicant was being transported back to Turkey to stand trial, as were the claimants in Medvedyev. It is common sense, Lord Collins said, that the ECHR should apply to these individuals, but that does nothing more than create another exception to the prevailing Banković rule that jurisdiction is primarily territorial. ${ }^{132}$

The facts of this case, Lord Collins concluded, came nowhere close to being within the exceptions to territorial jurisdiction clarified by the Grand Chamber in Banković. The cases employing the personal model were inconsistent with that precedent and should not be considered authoritative. Soldiers who are off-base in conflict zones would not be within the state's jurisdiction without fulfilling the Banković conditions for effective control or consent, invitation or acquiescence of the local government along with an exercise of governmental functions.

The majority of the Supreme Court agreed with Lord Collins, although Lord Hope DP expressed his opinion that the Supreme Court must go no further than the European Court in determining the proper scope of Article 1, and that Strasbourg is the appropriate forum to clarify the issue. ${ }^{133}$ Lord Mance wrote a powerful dissenting judgment. The Court's Al-Skeini judgment was handed down soon after this appeal, and confirmed that state agent authority and

\footnotetext{
127 Smith (No 1) (n 9) (251).

${ }^{128}$ Smith (No 1) (n 9) (289).

${ }^{129}$ Smith (No 1) (n 9) (295)-(298).

${ }^{130}$ Marković v Italy, Application no 1398/03, European Court of Human Rights, Grand Chamber, Judgment (14 December 2006) para 54.

${ }^{131}$ Smith (No 1) (n 9) (299).

132 Smith (No 1) (n 9) (306).

${ }^{133}$ Smith (No 1) (n 9) (92)-(93). Lord Hope was perhaps pre-empting a change in the legal position since Al-Skeini $v$ United Kingdom was pending at the European Court at the time the UKSC handed down its judgment.
} 
control is indeed a basis of jurisdiction under the Convention. Subsequently, the UKSC was asked again to consider whether British soldiers were within the UK's jurisdiction when on overseas deployments.

\subsection{Smith and Others $v$ Ministry of Defence}

\subsubsection{Facts and Appellate History}

The claims in Smith and others v Ministry of Defence were based on three sets of facts, all taking place during the invasion and occupation of Iraq. The facts can be divided into what Lord Hope DP called the 'Challenger' claims and the 'Snatch' claims. ${ }^{134}$ The 'Snatch' claims arose out of two separate incidents, in which Pte $\mathrm{E}$ and Pte $\mathrm{H}$ were travelling in lightly-armoured Snatch Land Rovers. Both were killed when improvised explosive devices ('IEDs') were detonated level with their vehicles. Neither vehicle had been fitted with functioning electronic counter-measures ('ECMs'), which might have prevented their deaths. The 'Challenger' claims were brought in negligence only.

In the High Court, Owen J handed down judgment for the Government, striking out the 'Snatch' claims. ${ }^{135}$ Quoting extensively from Smith No 1, the judge was clear that the soldiers had not been within the UK's jurisdiction at the time of their deaths for the reasons given in the first case. In the Court of Appeal, Moses LJ dismissed the appeal and affirmed the judge's ruling. ${ }^{136}$ Rimer LJ and Lord Neuberger $\mathrm{P}$ agreed ${ }^{137}$ that the Court in Al-Skeini had revived the personal model but that the facts did not disclose sufficient authority and control in this case. Jurisdiction is not conferred, they agreed,

By the status of armed forces owing allegiance to one of the high contracting parties, but by virtue of the exercise of physical power and control through the agency of its armed forces in an area over which it exercised effective control. ${ }^{138}$

The families lodged an appeal to the UKSC. Seven justices judged the appeal, of whom five (Lord Walker, Lady Hale, Lord Kerr, Lord Mance SCJJ and Lord Hope DP) had sat in Smith (No 1). On the question of $\mathrm{H}$ and $\mathrm{E}$ being within UK jurisdiction for the purposes of Article 1, the UKSC was unanimous. Lord Hope DP gave the leading judgment.

\footnotetext{
${ }^{134}$ Smith (No 2) (n 10) (9)(10).

${ }^{135}$ Smith and others v Ministry of Defence (2011) EWHC 1676 (QB), (2011) HRLR 765, (46).

${ }^{136}$ Smith and others v Ministry of Defence (2012) EWCA Civ 1365, (2013) 2 WLR 27, (32).

${ }^{137} \mathrm{Ibid}$, (65) (Rimer LJ); (66) (Lord Neuberger P).

${ }^{138} \mathrm{Ibid}$, (30) (Moses LJ).
} 


\subsubsection{Lord Hope DP}

At the time $\mathrm{H}$ and $\mathrm{E}$ were killed, power had passed to the Iraqi Interim Government, at whose request British forces remained in Iraq aiding in security and reconstruction efforts. The 'Snatch' claims were not concerned with effective control of territory, or a vacuum in the Convention legal space, but with state agent authority and control. ${ }^{139}$ In its judgment, the $A l$ Skeini Court had revived the state agent authority and control model of jurisdiction and determined that Convention rights can be 'divided and tailored'. ${ }^{140}$ As Lord Hope understood it,

The extra-territorial obligation of the contracting state is to ensure the observance of the rights and freedoms that are relevant to the individual who is under its agents' authority and control, and it does not need to be more than that. ${ }^{141}$

Extraterritorial jurisdiction for the purposes of Article 1 will depend upon the particular facts of a case. ${ }^{142}$ The fact that the European Court had never dealt with a case with analogous facts to the present one was no cause for concern, since ' $[\mathrm{t}]$ he whole structure of the judgment [in Al-Skeini] is designed to identify general principles with reference to which national courts may exercise their own judgment'. ${ }^{143}$ His Lordship went on to identify three principles in the Court's Al-Skeini judgment that demonstrate that the majority ruling in Smith (No 1) can no longer be considered good law.

First,

[T] he principle relating to state agent authority and control is to be regarded as one of general application. The words 'whenever the state through its agents exercises authority and control over an individual, and thus jurisdiction', can be taken to be a summary of the exceptional circumstances in which, under this category, the state can be held to be exercising its jurisdiction extra-territorially. ${ }^{144}$

Extraterritorial jurisdiction is an exception, requiring special justification, to the general territorial principle, but this should not be understood to create an especially high factual

\footnotetext{
139 Smith (No 2) (n 10) (31) (Lord Hope DP).

${ }^{140}$ Al-Skeini (n 86) paras 136-37.

${ }^{141}$ Smith (No 2) (n 10) (38).

142 Smith (No 2) (n 10) (42) (Lord Hope DP), quoting Al-Skeini (n 86) para 132.

${ }^{143}$ Smith (No 2) (n 10) (46) (Lord Hope DP).

144 Smith (No 2) (n 10) (46) (Lord Hope DP).
} 
threshold to establishing that individuals abroad are within the state's jurisdiction. 'Exceptional' merely denotes the frequency of the occurrence. ${ }^{145}$

Second, the judgment in Al-Skeini reconciled the inconsistency of the European Court's preceding jurisprudence. State agent authority and control is not linked to territory, but relates to the control of an individual, as the Court described that test in Issa.

The fact that Issa is included in para 136 as one of the examples of cases that fall within the general principle of state agent authority and control is particularly noteworthy. It anchors that case firmly in the mainstream of the Strasbourg court's jurisprudence on this topic. ${ }^{146}$

Whereas the UKSC in Smith (No 1) had dismissed Issa and its like as aberrations for being inconsistent with Banković, ${ }^{147}$ the Court's judgment in Al-Skeini means that '[i]t is Banković which can no longer be considered authoritative' on the question of the personal model of jurisdiction. $^{148}$

Finally, the Court laid to rest the notion that ECHR rights are indivisible. In Banković the Court said that if states are to ensure any ECHR rights, they must ensure all ECHR rights, which justified the high threshold of extraterritorial jurisdiction. But in relation to this ruling, His Lordship observed that

It was always going to be difficult to see how, if that was to be the guiding principle, it could be possible to accept that a state's armed forces abroad in whatever circumstances were within their jurisdiction for the purposes of Article 1 as its ability to guarantee the entire range of Convention rights would in many cases be severely limited. ${ }^{149}$

An 'all-or-nothing' approach to securing ECHR rights is inconsistent with the Court's ruling, like that of the Human Rights Committee, that the ECHR cannot be interpreted in such a way as to allow state agents to behave like 'gentlemen at home, hoodlums elsewhere'. ${ }^{150}$ It is now clear that states are only expected to secure the rights relevant to the nature and extent of the control exercised over an individual. ${ }^{151}$ When soldiers are deployed abroad, states' ability to fulfil their positive obligations to them arising out of the ECHR will be limited for a number of

\footnotetext{
145 Smith (No 2) (n 10) (46) (Lord Hope DP).

${ }^{146}$ Smith (No 2) (n 10) (47) (Lord Hope DP).

${ }^{147}$ Smith (No 1) (n 9) (307) (Lord Collins SCJ).

${ }^{148}$ Smith (No 2) (n 10) (47) (Lord Hope DP).

${ }^{149}$ Smith (No 2) (n 10) (48) (Lord Hope DP).

${ }^{150}$ Francisco Messineo, “Gentlemen at Home, Hoodlums Elsewhere'? The Extra-territorial Exercise of Power by British Forces in Iraq and the European Convention on Human Rights' (2012) 71 (1) Cambridge Law Journal 1518.

${ }^{151}$ Smith (No 2) (n 10) (49) (Lord Hope DP).
} 
reasons. But the state is still in a position of control over individual soldiers and through the exercise of its significant coercive powers is still capable of violating its negative obligations. If states were not bound by their negative obligations because it would be impracticable to expect them to fulfil their positive obligations, states could violate individual rights with impunity.

When it comes to the state's responsibility for the acts of its armed forces abroad, it seems to be 'the premise from which extra-territorial jurisdiction based on state agent authority and control has been developed' that soldiers are within the state's jurisdiction, though the Court has never directly answered this question. ${ }^{152}$ In Cyprus (No 1), the Commission decided that armed forces remain within the jurisdiction of the state. ${ }^{153}$ Lord Hope concluded

It is plain, especially when one thinks of the way the armed forces operate, that authority and control is exercised by the state throughout the chain of command from the very top all the way down to men and women operating in the front line. Servicemen and women relinquish almost total control over their lives to the state. It does not seem possible to separate them, in their capacity as state agents, from those whom they affect when they are exercising authority on the state's behalf. They are all brought within the state's article 1 jurisdiction by the application of the same general principle. ${ }^{154}$

Lord Hope also referred to the provision enacted by Parliament that soldiers are always subject to military law, wherever they are in the world, in or out of uniform. ${ }^{155}$

It is further evidence of the level of control exercised over soldiers by the state that they are generally beholden to military law without territorial limit and may, in serious cases, be court-martialled anywhere in the world. ${ }^{156}$ Lord Hope alludes to the fact that, as agents of the state, soldiers may by their actions bring individuals within the state's jurisdiction. But the fact that soldiers are the conduit through which the state's jurisdiction over individuals is exercised does not determine that soldiers themselves are within the state's jurisdiction. Simply by virtue of being state agents, soldiers are themselves under the authority and control of the state, irrespective of whether they are capable of bringing others within the state's jurisdiction by their actions or controlling a territory outside the state's own borders. This is quite a change from Moses LJ's dictum that soldiers are only within the state's jurisdiction to the extent that they are the conduit through which the state controls a territory.

\footnotetext{
${ }^{152}$ Smith (No 2) (n 10) (50) (Lord Hope DP).

${ }^{153}$ Cyprus v Turkey (No 1) (n 27) 136.

${ }^{154}$ Smith (No 2) (n 10) (52) (Lord Hope DP).

155 Smith (No 2) (n 10) (28) (Lord Hope DP); Armed Forces Act 2006, s 367(1).

${ }^{156}$ Letter from defence minister Anna Soubry MP to author (6 June 2014).
} 
Finally, Lord Hope referred to the Court's practice, approved of by the Grand Chamber, ${ }^{157}$ of using intrinsically non-binding instruments to aid in the interpretation of the Convention. Recommendation 1742 (2006) ${ }^{158}$ of the Parliamentary Assembly of the Council of Europe provides that

$[\mathrm{M}] \mathrm{embers}$ of the armed forces are citizens in uniform who must enjoy the same fundamental freedoms and the same protection of their rights and dignity as any other citizen, within the limits imposed by the specific exigencies of military duties. In para 3 it was emphasised that members of the armed forces cannot be expected to respect humanitarian law and human rights in their operations unless respect for human rights is guaranteed within the army ranks. ${ }^{159}$

Lord Mance's judgment in Smith (No 1) touched upon this recommendation, inasmuch as an armed conflict situation may mitigate the extent of the state's protective duty to its soldiers, but does not affect the existence of that duty. ${ }^{160}$

The Smith (No 1) judgment, Lord Hope concluded, should be departed from, since it is inconsistent with the Grand Chamber's guidance in Al-Skeini. The jurisdiction of the UK must, in line with this guidance, extend to securing the Convention rights of British soldiers on overseas deployments and, at the time of their deaths, $\mathrm{H}$ and $\mathrm{E}$ were within the jurisdiction of the UK for the purposes of Article 1. This ruling

[W]ould not be inconsistent with the general principles of international law, as no other state is claiming jurisdiction over them. The extent of that protection, and in particular whether the MOD was under a substantive duty of the kind for which the Snatch Land Rover claimants contend, is the question which must now be considered. ${ }^{161}$

The other Supreme Court justices sitting in judgment on this case all agreed with Lord Hope's opinion.

In a complete reversal of its earlier position, the UKSC laid down a new bottom line: British soldiers are within the jurisdiction of the UK, no matter where they are. Without the European Court's explicit clarification in Al-Skeini, Smith (No 2) would not have come before the higher courts at all, as the first Smith judgment would have prevented such claims on the basis that the soldiers were not within the UK's jurisdiction at the relevant times. Similarly, the

\footnotetext{
${ }^{157}$ Demir and Baykara v Turkey, Application no 34503/97, European Court of Human Rights, Grand Chamber, Judgment (12 November 2008) para 74.

${ }^{158}$ Council of Europe (Parliamentary Assembly) 'Recommendation 1742 (2006): Human Rights of Members of the Armed Forces' (11 April 2006).

${ }^{159}$ Smith (No 2) (n 10) (54) (Lord Hope DP) (emphasis added).

${ }^{160}$ Smith (No 1) (n 9) (192) (Lord Mance SCJ).

${ }^{161}$ Smith (No 2) (n 10) (55) (Lord Hope DP).
} 
Supreme Court's renewed investigation of the jurisdiction question would not have been necessary had the House of Lords' interpretation of Banković been correct. The European Court's judgment in Al-Skeini both enabled and necessitated that the UKSC change tack.

It is not clear whether the European Court would agree with the UKSC judgment that soldiers are within the jurisdiction of the state by virtue of the control and discipline that is characteristic of service in a modern military. It has been observed that the European Court has relied upon the personal model where jurisdiction under the spatial test cannot be satisfied but it would be unjust or arbitrary to deny that the state owed the applicant any responsibility under the Convention. ${ }^{162}$ The UKSC relied upon the personal model in Smith (No 2) to ensure that British soldiers will always enjoy their Convention rights when on deployment abroad, even though the UK will not, in most cases, have effective control of the foreign territories to which it deploys its armed forces.

The UKSC judgment, and that of the European Court in Al-Skeini, both reflect the fact that the international human rights instruments do not purport to regulate inter-state relationships. Although those instruments are treaties that form part of the larger corpus of PIL, which governs states' rights and duties in respect of each other, the human rights instruments regulate a different kind of state conduct, and the doctrinal tenets of jurisdiction in regulating inter-state relationships are inapt to define the limits of states' responsibilities to individuals. A state's ability to violate an individual's rights are not dependent upon that state's control of the territory, or of the exercise of governmental functions over it, as was demonstrated in Öcalan, Issa, Freda and so many other cases. By becoming a party to an international human rights instrument, a state undertakes to behave in certain accepted ways in relation to individuals. Whilst the treaties provide for mutual and collective enforcement of accepted standards, the primary obligation is to individuals. The concept of jurisdiction in PIL seeks to preserve states' sovereignty and the sovereign equality of states. But it would be wrong to use those foundational principles of international law to undermine state liability for violating obligations freely undertaken.

\section{Implications}

\footnotetext{
${ }^{162}$ Milanović (n 25) 186.
} 
The international and regional human rights are reciprocal agreements between states and therefore have a public law character. The doctrine of jurisdiction in PIL, although some parts of it are contested, has an accepted core meaning according to which the exercise of state power and authority is limited to the state's own territory. The European Court, and the other international human rights tribunals that have followed its lead, have interpreted jurisdiction in a wholly different way. Yet this should not be considered to have altered the nature and limits of states' powers vis-à-vis each other. The traditional concept of jurisdiction as limiting states' powers to their own territories except in certain circumstances continues to play a fundamental role in international law. If a state wishes to impose and enforce its law beyond its own borders, it may do so only in line with the concept of jurisdiction in PIL. The broad mantra that states' powers are limited to their territories is still good law.

IHRL creates a different kind of obligation. As previously mentioned, the international and regional human rights treaties create mutual collective enforcement mechanisms through bodies such as the Human Rights Committee, the European Court of Human Rights and the Inter-American Court of Human Rights. These supranational bodies may issue judgments or decisions requiring states to make reparations for violating individual rights or recommendations for future practice. But the principal obligation enshrined in the treaties is to individuals. That obligation is not delimited according to territory. One of the main factors motivating the restriction of states' jurisdiction to their national territories in PIL is the need to respect states' sovereignty and equality. If a state's agents exercise their own state's jurisdiction in the territory of another state, it may constitute a violation of those principles (where certain conditions are not met) and the territorial state may be able to seek redress.

But I would suggest that it is not a violation of state sovereignty to make states liable for their human rights violations anywhere in the world. In Öcalan, Turkey was liable for IHRL violations perpetrated against the applicant when he was arrested and detained in Kenya. Kenya could not be held liable for those violations under the ECHR, since it is not a party to that Convention and therefore not bound by its provisions. Imposing liability on Turkey ensured it upheld its Convention obligations but did not result in any damage to Kenya. In addition, whilst any Turkish reparations to Kenya for violating its sovereignty by enforcing its law in Kenyan territory would redress the violation of PIL, such reparations would be made to Kenya rather than to the individual whose rights were violated by the action itself. There is fragmentation in the two concepts of jurisdiction, but only where the nature of the obligations themselves requires it. Adoption of a PIL-inspired concept of jurisdiction linked to territory would 
undermine the nature and purpose of IHRL as a body of law creating or recognising obligations on states to behave in a certain way in respect of individuals. Rejecting that link, where the nature of obligations requires it, demonstrates the flexibility of PIL in adapting to new challenges and creating meaningful and practicable obligations on states. This should be celebrated as one of the strengths of PIL.

The most immediate implication of the European Court's Al-Skeini judgment and the UKSC's judgment in Smith (No 2) is that British soldiers are always within the UK's jurisdiction for the purposes of Article 1 of the ECHR. In Their Lordships' estimation, the military command structure and the culture of discipline and obedience and respect for superior orders and civilian control that characterise modern military service ${ }^{163}$ equate to 'authority and control'. States exercising effective control of territory are required to secure the whole pantheon of ECHR rights. When jurisdiction is exercised through state agent authority and control, states are only required to ensure those rights relevant to the nature and extent of the control. It has not yet been judicially established which rights are relevant to the nature and extent of the military command structure. I would be inclined to suggest that, on deployment abroad, states must be required to abide by their negative obligations arising out of the ECHR and must do nothing that would infringe soldiers' rights. In each individual case domestic courts and the European Court might determine that any particular infringement was justified as 'necessary in a democratic society' 164 or within the prudentially-determined limitations to ECHR rights. But the state will be liable in principle for any actual violation suffered by an individual within their authority and control. The authority and control exerted over soldiers gives states the capability to violate individual rights, a capability that must be curtailed.

Whether the state can be liable for not upholding its positive obligations to soldiers on deployment is less certain. The positive obligations arising from ECHR require states to take positive steps, not only to refrain from violating individual rights, but to secure the ECHR rights. This requires states to prevent individual rights from being violated. In many cases enacting and enforcing a legal regime that deters and punishes wrongdoing (in criminal prosecutions or civil actions for damages where appropriate) will satisfy this obligation. The state may make provisions in military law that impose civil or criminal liability on soldiers in

\footnotetext{
${ }^{163}$ For a detailed study of military professionalism, obedience and the armed forces' relationship with civil government, see Samuel P Huntington, The Soldier and the State: The Theory and Politics of the Civil-Military Relationship (Cambridge, MA, Harvard University Press, 1957).

164 This is the limitation clause standard to the rights contained in Articles 8-11, ECHR. Other rights contained in the ECHR are drafted in such a way as to have allowed the European Court to interpret limitations to those rights.
} 
order to fulfil its positive obligations. But the greater problem is how to protect soldiers from human rights violations perpetrated by the enemy. IHRL continues to apply in times of armed conflict, ${ }^{165}$ and human rights are not a 'fair-weather friend to humanity' ${ }^{166}$ How those positive obligations might be implemented in times of armed conflict, and indeed whether those positive obligations exist at all in armed conflict, is the question posed after Smith (No 2). The UKSC's judgment that British soldiers are within the UK's jurisdiction for the purposes of IHRL requires that this question now be answered. This poses tremendous difficulties, in ensuring that rights are adequately protected whilst balancing those rights with military needs and subjecting states to obligations that are realistic and practicable. In this context, rigid rules are impractical and this kind of decision will always have to be taken on an ad hoc basis, taking into account all the circumstances of the case including the nature of the violation complained of.

One question is whether the spatial model of jurisdiction is in any way relevant after the Al-Skeini judgment. Whilst the spatial model of jurisdiction is more restrictive than the personal, it is difficult to imagine any situation in which a state has effective control of a territory but not control of the individual. Indeed, in many cases in which the personal model of jurisdiction has been invoked, state agents had physical control over an individual in the form of detention. But the control and authority can be established by the exercise of a legal power over an individual as well. Do we really need the territorial model at all?

It might well be argued that, since the European Court tends not to overrule its own previous judgments, the territorial model was included as a mode of exercising extraterritorial jurisdiction so as to perpetuate the illusion that Banković was decided correctly and was still 'good law'. However, it must be recognised that the nature and extent of control over an individual is very different when a state has control of territory than when it merely has someone in detention. Control of territory connotes a substantial physical presence and power to enact and enforce legal measures that affect the daily way of life of the whole local population. It is this control of the population, rather than control of the territory itself, that cements the ECHR obligations.

Where a state has effective control of a territory, it has greater scope to enact laws that may violate the whole range of Convention rights, and a better opportunity to take measures that will guarantee all of the Convention rights. Where state agents have physical control over an individual, they enjoy a certain level of power over the most basic rights (such as the right

\footnotetext{
${ }^{165}$ Legality on the Threat or Use of Nuclear Weapons (Advisory Opinion) 1996 ICJ Rep 226, para 25

${ }^{166}$ Elizabeth Wicks, The Right to Life and Competing Interests (Oxford, Oxford University Press, 2010$) 79$.
} 
to life and freedom from torture), but are not in a position to put in place the legal measures to affect rights such as the right to marry. Effective control of territory is still relevant for jurisdiction, but only because it suggests a more complete level of control over individuals.

In this article I have discussed 'extraterritorial' application of the Convention, but in truth this is a misnomer. Since the Convention is applicable wherever a state has control over an individual, and states, acting through their agents, may have control over individuals anywhere in the world (regardless of how we might justify that control under public international law), it is not just about states' own territories. States are presumed to exercise jurisdiction throughout their territories, but that is a rebuttable presumption. The presumption stems not from the relationship between territory and statehood, but from the fact that control over territory entails a high level of control over individuals. Though states are expected to have control over territories to which they lay claim, the opposite can be true, as the Court has demonstrated in its Ilaşcu and Cyprus judgments. Jurisdiction for the purposes of Article 1 is not concerned with whether state agents are acting abroad lawfully, only that someone is within their power as a matter of fact.

\section{Conclusion}

For as long as the Grand Chamber's Banković judgment remained the leading case on the issue, the concept of jurisdiction in human rights law replicated the strong relationship between jurisdiction and territory as in public international law. This was an aberration, as PIL and IHRL regulate very different kinds of state behaviour. Whilst PIL jurisdiction determines the legality of states' actions beyond their own borders (hence the important link to territory), that makes no impact on whether state agents are in a position to affect individuals' enjoyment of their fundamental rights. In effect, the IHRL treaties, which are prefaced with references to the universality and inherence of human rights, create enforceable rights for all people in the world. Those treaties only bind the states that become parties to them, but those states are bound in respect of everyone within their authority and control.

One might take a cultural relativist position and claim that the interpretation of the universal rights in the Convention reflects the values of Council of Europe Member States and should not be foisted upon other cultures. ${ }^{167}$ If one accepted this position and accordingly

${ }^{167} R$ (Al-Skeini) (n 85) (78) (Lord Rodger). 
adopted a narrow interpretation of Article 1, jurisdiction would maintain some link to territory, but on a basis other than arbitrary geographical limits. This position has, however, been rubbished as 'crude chauvinism'. ${ }^{168}$ Ultimately, states parties to the Convention agree that their agents should treat individuals with a minimum standard of dignity and respect. They should not be allowed to abandon that standard because people with different cultural backgrounds have different conceptions of dignity and respect.

Borrowing the Human Rights Committee's interpretation of the ICCPR, the European Court of Human Rights has judged that the Convention must not be interpreted in such a way that permits state agents to commit violations of the Convention abroad that they could not permissibly commit at home. ${ }^{169}$ Whether an individual's human rights have been violated does not depend upon the state's relationship to territory. As such, the traditional conception of jurisdiction in PIL as having a strong link to statehood and territory has no place in IHRL. But this should not be seen as undermining the traditional idea of jurisdiction. One word can have multiple meanings in different contexts. Perhaps, for the avoidance of doubt, the drafters of the IHRL treaties should have explicitly defined jurisdiction, or better still, avoided the word completely. It is of the utmost importance that we be sure to apply the right definition in the right place.

\footnotetext{
168 Ralph Wilde, 'Triggering State Obligations Extraterritorially: The Spatial Test in Certain Human Rights Treaties' (2007) 40 Israel Law Review 503-26, 522.

${ }^{169}$ Issa (n 39) para 31.
} 